\title{
PERAN PUSAT KEGIATAN BELAJAR MASYARAKAT (PKBM) DALAM MENGURANGI BUTA AKSARA DI KABUPATEN KARIMUN*)
}

\section{THE ROLE OF COMMUNITY LEARNING CENTER TO REDUCE ILLITERACY RATE IN KARIMUN REGENCY}

\author{
Ais Irmawati \\ Pusat Penelitian Kebijakan Pendidikan dan Kebudayaan \\ Jalan Jenderal Sudirman, Gedung E, Lantai 19 \\ e-mail:ais.irmawati@kemendikbud.go.id
}

Naskah diterima tanggal: 7-04-2017, disetujui tanggal: 24-06-2017

\begin{abstract}
This study is to describe 1) the job profession of Karimun Regency community, 2) public perception of education and 3) the role of the Community Learning Center (CLC) in reducing illiteracy. This research uses descriptive qualitative method. The data were collected through in-depth interviews to study the community, community leaders, and education service officers; and the conduct of Focused-Group Discussion. The results of this study indicate that 1) The job of Karimun Regency is labours, fishermen, divers and traders, as well as migrant worker using a tourist passport that does not require education, and government employee, 2) The community has a low awareness of the importance of education, since without schooling they can earn substantial income, and 3) The role of CLC in Karimun is very important in reducing illiteracy marked by the large number of adult participants attending graded literacy programs $A, B$, and $C$, as well as Self Employment and Literacy Program. In addition, children participating in Play and Early Childhood Groups. The study concludes that CLC role is very important in reducing illiteracy in Karimun regency, because of the flexibility learning time compared to formal education. However, the obstacle of CLC in Karimun are working hours of students, difficulty to reach the learning center location, lack of tutors and honorarium tutors.
\end{abstract}

Keyword: role of community learning center, illiteracy, Karimun Regency

\begin{abstract}
Abstrak: Penelitian ini bertujuan untuk mendeskripsikan 1) masyarakat Kabupaten Karimun berdasarkan pekerjaan; 2) persepsi masyarakat terhadap pendidikan; dan 3) peran Pusat Kegiatan Belajar Masyarakat (PKBM) dalam mengurangi buta aksara. Penelitian ini menggunakan metode kualitatif deskriptif. Pengambilan data dilakukan dengan wawancara mendalam terhadap warga belajar, tokoh masyarakat, dan Pegawai Dinas Pendidikan serta Diskusi Kelompok Terpimpin. Hasil penelitian ini menunjukkan bahwa 1) Pekerjaan masyarakat Kabupaten Karimun adalah buruh, nelayan, penyelam, pedagang, menjadi Tenaga Kerja Indonesia (TKI) dengan menggunakan paspor wisatawan yang tidak mensyaratkan pendidikan, dan sebagai Pegawai Negeri Sipil, 2) Masyarakat mempunyai kesadaran yang rendah terhadap pentingnya pendidikan, mengingat tanpa bersekolah pun mereka dapat memperoleh penghasilan yang besar, dan 3) Peran PKBM di Karimun sangat penting dalam mengurangi buta aksara ditandai dengan banyaknya peserta dewasa yang mengikuti Program Keaksaraan Paket A, B, dan C, serta Keaksaraan Usaha Mandiri dan Keaksaraan. Selain itu, anak-anak juga mengikuti Kelompok Bermain dan Pendidikan Anak Usia Dini. Penelitian ini menyimpulkan Peran PKBM sangat penting dalam mengurangi buta
\end{abstract}

\footnotetext{
*) Penelitian ini adalah bagian dari Penelitian Akulturasi Kebudayaan di Daerah 3T yang dilakukan oleh Pusat Penelitian Kebijakan Pendidikan dan Kebudayaan yang bersumber pada APBN 2016
} 
aksara di Kabupaten Karimun, karena waktu belajar di PKBM lebih fleksibel dibandingkan dengan sekolah formal. Hambatan pelaksanaan PKBM di Karimun, antara lain jam kerja warga belajar, jauh dan sulitnya jarak tempuh, keterbatasan jumlah tutor dan besar honor tutor.

Kata Kunci: peran PKBM, buta aksara, Kabupaten Karimun.

\section{PENDAHULUAN}

Agenda prioritas dalam Rencana Pembangunan Jangka Menengah Nasional (RPJMN) 2015-2019, antara lain membangun Indonesia dari pinggiran dengan memperkuat daerah-daerah dan desa dalam kerangka negara kesatuan; meningkatkan kualitas hidup manusia Indonesia; dan meningkatkan produktivitas rakyat dan daya saing di pasar internasional sehingga Indonesia bisa maju dan bangkit bersama bangsa-bangsa Asia lainnya (Republik Indonesia, 2015).

Dalam bidang pendidikan, Undang-Undang Sistem Pendidikan Nasional (UUSPN) Nomor 20 Tahun 2003, Pasal 5, ayat (1) menyatakan, "Setiap warga negara mempunyai hak yang sama untuk memperoleh pendidikan yang bermutu." Ayat (5) menyatakan, "Setiap warga negara berhak mendapat kesempatan meningkatkan pendidikan sepanjang hayat." (Republik Indonesia, 2003)

Untuk mewujudkan pendidikan bagi seluruh warga Negara Indonesia, terdapat tiga bentuk pendidikan bagi seluruh warga Negara Indonesia, yaitu pendidikan formal, pendidikan nonformal, dan pendidikan informal. Hal ini sesuai dengan UUSPN tahun 2003, Pasal 26, ayat (1) Pendidikan nonformal diselenggarakan bagi warga masyarakat yang memerlukan layanan pendidikan yang berfungsi sebagai pengganti, penambah, dan/atau pelengkap pendidikan formal dalam rangka mendukung pendidikan sepanjang hayat; ayat (2) Pendidikan nonformal berfungsi mengembangkan potensi peserta didik dengan penekanan pada penguasaan pengetahuan dan keterampilan fungsional serta pengembangan sikap dan kepribadian profesional.

Kabupaten Karimun merupakan salah satu kabupaten yang termasuk dalam daerah terluar
Indonesia, karena posisi geografisnya di sebelah utara berbatasan langsung dengan Philip Channel Singapura dan Semenanjung Malaysia. Keunikan lainnya, kabupaten ini merupakan salah satu kabupaten di Kepulauan Riau yang terdiri atas 250 pulau besar dan kecil, 57 pulau di antaranya sudah berpenghuni. Adapun peta Kabupaten Karimun dapat dilihat pada Gambar 1.

Pada tahun 2015 jumlah sekolah dasar (SD) dan madrasah ibtidaiyah (MI) di Kabupaten Karimun berjumlah 148 unit, 29.580 siswa, dan 2.033 guru Pada tingkat pendidikan menengah, jumlah SMP sederajat berjumlah 60 unit, 14.493 siswa, dan 1.043 guru. Sedangkan untuk sekolah menengah atas, Kabupaten Karimun saat ini memiliki 18 sekolah menengah atas, 6.444 siswa, dan 446 guru. Serta terdapat 5 Madrasah Aliyah, 410 siswa, dan 81 orang guru; serta 8 sekolah jenjang kejuruan, 3.061 siswa, dan 220 orang guru (Republik Indonesia, 2016)

Berdasarkan pendidikan tertinggi yang ditamatkan dan jenis kegiatan oleh penduduk berusia 15 tahun ke atas di Kabupaten Karimun 2015 dapat dilihat pada Tabel 1. Dalam Tabel 1, terlihat jumlah penduduk usia 15 tahun ke atas baik angkatan kerja maupun bukan angkatan kerja yang belum pernah bersekolah sebanyak 11.419 , yang belum tamat SD sebesar 26.774, SMP sebanyak 84.104 orang, SMA dan SMK sebanyak 60.374 orang, dan Perguruan Tinggi sebesar 20.292 orang. Artinya pada tahun 2015, di Kabupaten Karimun masih terdapat sebesar $50 \%$ penduduk yang berpendidikan setingkat sekolah dasar ke bawah, $16 \%$ di tingkat SMP, $25 \%$ di tingkat SMA, dan $8 \%$ perguruan tinggi. Berdasarkan data di atas tampak bahwa peran Pendidikan Nonformal, khususnya Pusat Kegiatan Belajar Masyarakat di Kabupaten 


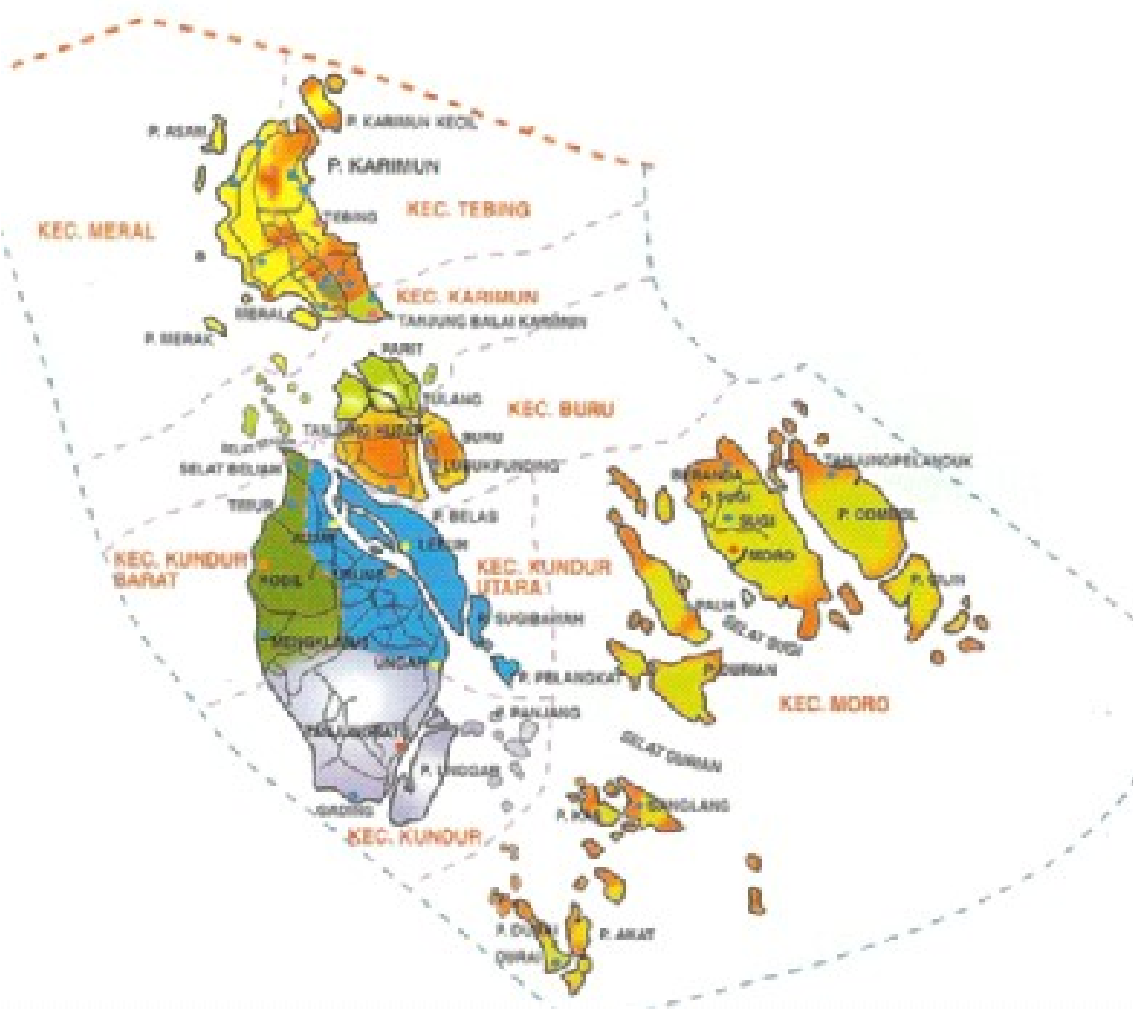

Gambar1. Peta Kabupaten Karimun

Sumber: Republik Indonesia (2016)

Tabel 1. Jumlah Penduduk Berumur 15 Tahun ke atas menurut Pendidikan tertinggi yang ditamatkan dan jenis kegiatan di Kabupaten Karimun 2015

\begin{tabular}{lcrrr}
\hline $\begin{array}{l}\text { Pendidikan Tertinggi yang } \\
\text { Ditamatkan }\end{array}$ & \multicolumn{3}{c}{ Angkatan Kerja } & \multicolumn{2}{c}{$\begin{array}{c}\text { Bukan } \\
\text { Angkatan Kerja }\end{array}$} \\
\cline { 2 - 5 }$(1)$ & Bekerja & $\begin{array}{c}\text { Pengangguran } \\
\text { Terbuka }\end{array}$ & Jumlah & $(5)$ \\
Tidak/Belum Pernah Sekolah & \multicolumn{1}{c}{$(2)$} & $(3)$ & \multicolumn{1}{c}{$(4)$} & 4473 \\
Tidak/Belum Tamat SD & 3473 & & 3473 & 9248 \\
Sekolah Dasar & 8154 & 609 & 8763 & 22352 \\
Sekolah Menengah & 30162 & 714 & 30876 & 15584 \\
Sekolah Menengah Atas & 11696 & 479 & 12175 & 7972 \\
Sekolah Menengah Atas Kejuruan & 19507 & 1109 & 20616 & 1748 \\
Diploma I/II/III/Akademi & 4544 & 167 & 4711 & 624 \\
Universitas & 1799 & - & 1799 & 1234 \\
Jumlah & 7338 & 80 & 7418 & 63235 \\
\hline
\end{tabular}

Sumber: Survey Angkatan Kerja Nasional Agustus dalam Karimun Dalam Angka tahun 2016 (Republik Indonesia, 2016)

Karimun mutlak diperlukan.

Dalam UUSPN Tahun 2003 Pasal 1 ayat (1), yang dimaksud dengan pendidikan adalah usaha sadar dan terencana untuk mewujudkan suasana belajar dan proses pembelajaran agar peserta didik secara aktif mengembangkan potensi dirinya untuk memiliki kekuatan spiritual keagamaan, pengendalian diri, kepribadian, kecerdasan, akhlak mulia, serta keterampilan yang diperlukan dirinya, masyarakat, bangsa dan Negara (Republik Indonesia, 2003). 
Dalam UUSPN Tahun 2003 Pasal 1 ayat (12) yang dimaksud dengan Pendidikan nonformal adalah jalur pendidikan di luar pendidikan formal yang dapat dilaksanakan secara terstruktur dan berjenjang (Republik Indonesia, 2003). Pendidikan nonformal meliputi pendidikan kecakapan hidup, pendidikan anak usia dini, pendidikan kepemudaan, pendidikan pemberdayaan perempuan, pendidikan keaksaraan, pendidikan keterampilan dan pelatihan kerja, pendidikan kesetaraan, serta pendidikan lain yang ditujukan untuk mengembangkan kemampuan peserta didik (UUSPN Tahun 2003 Pasal 27 ayat (3)) (Republik Indonesia, 2003).

Satuan pendidikan nonformal terdiri atas lembaga kursus, lembaga pelatihan, kelompok belajar, Pusat Kegiatan Belajar Masyarakat (PKBM), dan majelis taklim, serta satuan pendidikan yang sejenis (Republik Indonesia, 2003). PKBM adalah satuan pendidikan nonformal yang menyelenggarakan berbagai kegiatan belajar sesuai dengan kebutuhan masyarakat atas dasar prakarsa dari, oleh, dan untuk masyarakat (Departemen Pendidikan Nasional, 2003). PKBM yang didirikan dapat menyelenggarakan program: 1) pendidikan anak usia dini, 2) pendidikan keaksaraan, 3) pendidikan kesetaraan, 4) pendidikan pemberdayaan perempuan, 5) pendidikan kecakapan hidup, 6) pendidikan kepemudaan, 7) pendidikan keterampilan kerja, 8) pengembangan budaya baca, dan 9) pendidikan nonformal lain yang diperlukan masyarakat (Departemen Pendidikan Nasional, 2003).

Tujuan penting dalam pengembangan PKBM menurut Sihombing dan Gutama dalam Saepudin, Saepudin, Sadikin, dan Saripah (2016) adalah pertama, memberdayakan masyarakat agar mampu mandiri (berdaya). Kedua, meningkatkan kualitas hidup masyarakat baik dari segi sosial maupun ekonomi. Ketiga, meningkatkan kepekaan terhadap masalahmasalah yang terjadi dilingkungannya sehingga mampu memecahkan permasalahan tersebut.

Dalam pandangan Tohani (2009), program PNF mampu memberikan manfaat kepada warga belajarnya, mampu menjadikan warga belajar menguasai pengetahuan dan keterampilan tertentu yang dapat digunakan untuk meningkatkan kualitas hidupnya, menyebabkan mereka mampu berfikir relevan dalam memecahkan masalah yang dihadapi, memudahkan mereka untuk bekerja baik mandiri maupun bersama orang lain, dan mampu secara aktif berpartisipasi dalam kegiatan di masyarakat bahkan mampu membelajarkan masyarakat lain. Sedangkan Septiani (2016) menyebutkan bahwa dalam memfasilitasi belajar masyarakat, PKBM mempunyai tugas dan fungsi sebagai berikut: 1) mengidentifikasi kebutuhan masyarakat, 2) menyelenggarakan program pendidikan, 3) menyediakan sumber daya potensial, 4) membangun kerja sama dengan mitra, 5) memonitoring dan mengevaluasi program, 6) pendidikan alternatif, 7) pusat informasi dan sumber belajar, dan 8 ) pengembangan masyarakat. Untuk memfasilitasi masyarakat belajar sepanjang hayat, maka PKBM perlu melakukan perencanaan atau mendesain instruksional, yaitu menganalisis kebutuhan masyarakat, merancang program pembelajaran; mengembangkan bahan strategi, serta sumber belajar yang beraneka ragam; mengimplementasikan bahan, metode pembelajaran, dan berbagai sumber belajar dalam proses pembelajaran; serta melakukan evaluasi secara berkala.

Hiryanto (2008) menyimpulkan bahwa pemberdayaan sangat identik dengan pendidikan dan merupakan hakekat pendidikan itu sendiri, karena apa yang disebut dengan pendidikan termasuk pendidikan luar sekolah atau pendidikan nonformal adalah usaha memberdayakan manusia, memampukan manusia, mengembangkan talenta-talenta yang ada pada diri manusia agar dengan kemampuan/potensi yang dimilikinya dapat dikembangkan melalui pendidikan/pembelajaran.

Dalam penjelasan UUSPN Pasal 26 ayat (3) dijelaskan bahwa Pendidikan kecakapan hidup (life skills) adalah pendidikan yang memberikan kecakapan personal, kecakapan sosial, kecakapan intelektual, dan kecakapan vokasional 
untuk bekerja atau usaha mandiri. Pendidikan kepemudaan adalah pendidikan yang diselenggarakan untuk mempersiapkan kader pemimpin bangsa, seperti organisasi pemuda, pendidikan kepanduan/kepramukaan, keolahragaan, palang merah, pelatihan, kepemimpinan, pecinta alam, serta kewirausahaan. Pendidikan pemberdayaan perempuan adalah pendidikan untuk mengangkat harkat dan martabat perempuan. Pendidikan kesetaraan adalah program pendidikan nonformal yang menyelenggarakan pendidikan umum setara SD/MI, SMP/MTs, dan SMA/MA yang mencakup program paket $A$, paket $B$, dan paket $C$. Pendidikan dan pelatihan kerja dilaksanakan untuk meningkatkan kemampuan peserta didik dengan penekanan pada penguasaan keterampilan fungsional yang sesuai dengan kebutuhan dunia kerja.

Hartini, dkk. (2015) menyatakan bahwa pendidikan keaksaraan ini membawa pengaruh bagi warga belajar baik dalam tingkat sosial maupun dalam tingkat ekonomi. Peningkatan dalam hal sosial dari warga belajar ini adalah tingkat percaya diri yang meningkat untuk ikut berpartisipasi aktif dalam kegiatan organisasi yang ada di masyarakat Peningkatan warga belajar dalam tingkat ekonomi keluarga dapat dilihat dari peningkatan pendapatan dan peningkatan dalam kegiatan berwirausaha warga belajar yang bertujuan untuk membantu meningkatkan tingkat ekonomi dalam keluarganya yang diperoleh selama proses pembelajaran program keaksaraan fungsional.

Beberapa penelitian mengenai PKBM telah dilakukan. Salah satu adalah mengenai Efektivitas PKBM Sejahtera di Kelurahan Parit Mayor Kecamatan Pontianak Timur yang dilakukan oleh Defriana (2015). Hasil penelitiannya menunjukkan bahwa pelaksanaan PKBM Sejahtera telah menjalankan tugasnya sebagai penyelenggara pendidikan kesetaraan dengan baik, didukung oleh tutor yang memiliki motivasi mengajar sangat tinggi. Namun, terbatasnya waktu belajar dan rendahnya kehadiran warga belajar yang sebagian besar hanya ingin mendapatkan ijazah tidak menyadari bahwa mengikuti proses belajar itu sangat penting, selain mendapatkan ilmu pengetahuan juga untuk mengembangkan potensi, sikap dan kepribadiannya, menyebabkan kegiatan belajar mengajarnya tidak optimal.

Sari (2014) dalam penelitiannya menunjukkan bahwa pengelolaan PKBM berjalan efektif. Semua perencanaan, pengorganisasian, pelaksanaan, pengawasan serta evaluasi terhadap program-program yang akan dan yang sudah dilaksanakan dengan baik sesuai dengan standar pengelolaan PKBM yang telah ditentukan. Hasil penelitian lain yaitu Rizqi (2008) tentang Peran PKBM Suka Caturtunggal dalam Peningkatan Sumber Daya Manusia di Kelurahan Caturtunggal, Depok, Sleman, Yogyakarta; Sutisna, Sinaga, Rosfiantika (2012) tentang Peranan PKBM (Pusat Kegiatan Belajar Masyarakat) dalam Menumbuhkan Minat Baca Warga Belajar Paket $\mathrm{C}$ di PKBM Jembar Kabisa, Desa Sukahayu, Kabupaten Sumedang. Hasil-hasil penelitian dimaksud menyimpulkan bahwa PKBM ini memiliki peranan yang sangat penting dalam menumbuhkan minat baca warga belajar.

Berbeda dengan penelitian terdahulu, studi ini difokuskan pada Peran Pusat Kegiatan Belajar Masyarakat (PKBM) dalam Mengurangi Buta Aksara di Kabupaten Karimun. Pemilihan topik ini didasarkan atas keunikan Kabupaten Karimun yang selain merupakan daerah terluar Indonesia, mempunyai 251 buah pulau, belum semuanya berpenghuni, keterbatasan fasilitas listrik, dan transportasi, juga kecenderungan bahwa pendidikan formal tidak cukup mampu melayani penduduk usia sekolah di daerah tersebut.

Ada tiga masalah yang diajukan dalam studi ini, yaitu, 1) bagaimana deskripsi masyarakat Kabupaten Karimun berdasarkan pekerjaan? 2) Bagaimana persepsi masyarakat terhadap pendidikan?; dan 3) Bagaimana peran PKBM dalam mengurangi buta aksara di Kabupaten Karimun?

Berdasarkan latar belakang dan pertanyaan penelitian tersebut maka tujuan penelitian ini yaitu untuk 1) mendeskripsikan masyarakat Kabupaten Karimun berdasarkan pekerjaan, 2) 
persepsi masyarakat Kabupaten Karimun terhadap pendidikan; dan 3) peran PKBM dalam mengurangi buta aksara di Kabupaten Karimun.

\section{METODE}

Penelitian ini menggunakan metode deskriptif kualitatif. Silalahi (2009) menuliskan bahwa penelitian deskriptif banyak imponderabilia (halhal yang nampaknya tidak penting, tetapi pada hakekatnya sangat berperan, seperti nilai-nilai dan sebagainya) dari kehidupan sosial seharihari. Penelitian deskriptif menyajikan satu gambar yang terperinci tentang satu situasi khusus, bentuk sosial, atau hubungan. Creswell dalam Silalahi (2009) mendefinisikan penelitian kualitatif sebagai suatu proses penyelidikan untuk memahami masalah sosial berdasarkan pada penciptaan gambaran holistik lengkap yang terbentuk dengan kata-kata, melaporkan pandangan informan secara terperinci, dan disusun dalam sebuah latar alamiah.

Penelitian ini dilakukan di Kabupaten Karimun dengan melibatkan warga belajar PKBM, Tokoh Masyarakat, dan Pegawai kantor Dinas Pendidikan dan Kebudayaan Kabupaten Karimun. Pemilihan sampel dilakukan dengan snowball; sebagai informan kunci adalah pejabat di lingkungan Kantor Pendidikan dan Kebudayaan Karimun bidang Pendidikan Nonformal.

Pengumpulan data dilakukan dengan cara wawancara mendalam dan dianalisis lebih mendalam dalam sebuah diskusi kelompok terpumpun (FGD). Menurut Miles dan Huberman dalam Silalahi (2009), kegiatan analisis terdiri dari tiga alur kegiatan yang terjadi secara bersamaan, yaitu reduksi data, penyajian data, dan penarikan kesimpulan/verifikasi yang jalin menjalin merupakan proses siklus dan interaktif pada saat sebelum, selama, dan sesudah pengumpulan data

\section{HASIL DAN PEMBAHASAN \\ Masyarakat Kabupaten Karimun berdasarkan pekerjaan}

Berdasarkan data BPS Kabupaten Karimun mengenai kegiatan utama yang dilakukan seminggu yang lalu dan jenis kelaminnya untuk usia 15 tahun ke atas, diketahui bahwa 91.902 orang, merupakan angkatan kerja, dimana 86.673 orang dari jumlah itu kegiatan utamanya adalah bekerja (working) (Republik Indonesia, 2016)

Pekerjaan penduduk Kabupaten Karimun beragam, mulai dari nelayan, petani, berburu, pekerja di pabrik-pabrik yang banyak terdapat di Pulau Karimun; ada juga, pemulung dan juga pedagang di daerah lain di Kabupaten Karimun. Hal semacam ini disampaikan oleh Bapak Halil, ketua PKBM Bakti Negeri, "Secara geografis posisi pulau Kundur itu sudah diposisikan sebagai daerah pertanian. Jadi beda dengan Pulau Karimun, merupakan daerah industri. Kemudian ada daerah, Moro mungkin daerah perikanan. Kemudian Pulau Buru daerah wisata." (FGD, 4 Agustus 2016)

Menurut data Dinas Tenaga Kerja Kabupaten Karimun Tahun 2016, terdapat 33 perusahaan berbentuk PT dan 2 perusahaan berbentuk CV yang berada di Kabupaten tersebut, yang terpusat di Pulau Karimun. 24 dari Perusahaan tersebut mempunyai tenaga kerja lokal, maupun tenaga kerja asing. Sedangkan sisanya hanya mempekerjakan warga lokal.

Seseorang tenaga kerja lokal di posisi tertentu tidak harus mempunyai pendidikan tinggi untuk menjadi pekerja di perusahaan tersebut. Sebagai contoh, untuk menjadi seorang helper di PT. Saipem, seorang yang tanpa ijazah, dapat memperoleh penghasilan sebesar Rp 6-7 juta/bulan. Bila pekerjaannya dianggap baik, maka berdasarkan kepercayaan, dia dapat diangkat untuk menempati posisi yang lebih tinggi, demikian seterusnya; hingga kemudian ada posisi yang mempersyaratkan pendidikan tertentu., Bapak Raja menyatakan, "Kami PNS, kalah Iho gaji dengan mereka nggak sekolah itu kerja di Saipem. Dia nggak tamat SMP itu gajinya puluhan juta Iho. Nggak percaya? Kita cek ke sana. Mereka hanya tamat SD. Kita pegawai negeri, gaji pokok baru $2.800 .000,-$. Saya gaji pokok tamat kuliah nggak sampai 5 juta Iho. Mereka nggak tamat SD 7 juta itu tanpa lembur, seneng banget mereka." 
(FGD, 4 Agustus 2016)

Gambar 1 menjelaskan bahwa kebanyakan wilayah Kabupaten Karimun dapat dijangkau dengan mengunakan transportasi laut, baik berupa kapal ferry, ataupun pompong. Nama yang beragam ini menunjukkan besar-kecilnya ukuran kapal laut tersebut. Transportasi laut dapat beroperasi bergantung pada cuaca, yang dapat saja berubah dengan cepat. Bila cuaca terang, transportasi laut dapat berjalan sesuai jadwal, namun ketika ombak dan angin besar melanda, dapat saja syah bandar menghentikan pengoperasian kapal sampai waktu yang tidak dapat ditentukan sebelumnya.

Adapun transportasi darat dalam artian angkutan umum, hanya tersedia di Pulau Karimun, dan tidak menjangkau seluruh lokasi. Oleh karena itu warga Kabupaten Karimun biasa mempunyai motor sebagai sarana transportasi darat. Commuter seperti pedagang, pekerja pabrik, dan atau PNS yang sering harus menyeberangi pulau, biasa memiliki motor di kedua pulau yang sering dikunjunginya. Hal semacam ini diistilahkan oleh Bapak Katwanto, Sekretaris PKBM Al Falah sebagai daerah dengan cost biaya tinggi. Lebih jelas, Pak Katwanto menyampaikan, "Karimun ini itu adalah daerah dengan biaya tinggi Pak. Cost biayanya tinggi. Tak sama dengan di Jawa, Pak. Barangkali kalau di sana, kasarnya biaya dari Jakarta ke Jogja. Itu naik kereta api 300 langsung sampai. Kami yang perjalanan taruhlah 15 menit aja, udah 25 ribu. Itu baru yang di laut. Makanya saya bilang Karimun di daerah yang cost biayanya tinggi. Jadi berangkat dari situ, Sebenarnya saya berharap ada pemetaan dari pemerintah pusat terhadap daerah-daerah yang seperti ini. Ini macamnya program-program pemerintah yang dilemparkan ke daerah itu pukul rata sama. Kalau misalnya di daerah yang tak seperti di Karimun dipukul sama, itu ya efeknya kami di daerah yang seperti ini tak jadi apa-apa. kalau seandainya pusat memberikan dana stimulan misalnya 600.000,-. Untuk ongkos nak beli, naik pompong tak cukup." (wawancara, 4 Agustus 2016)
Di Kabupaten Karimun terdapat 3 wilayah yang dihuni oleh suku laut yang merupakan suku terasing, yaitu: 1) Komunitas Suku Tanjung Semangat di Kundur Utara yaitu namanya, 2) Suku Laut Bubu atau suku Wasing di Kundur, dan 3) Komunitas Suku Laut Prayun di Kundur Barat, dengan pencaharian pokok sebagai pemulung, berburu, mencari kayu, penyelam, nelayan, kuli panggul pikul, dan berdagang, tergantung apa yang ada pada hari tersebut. Artinya, kalau pada hari itu ada kapal yang bongkar muat, maka mereka dapat bekerja sebagai kuli panggul pikul, yang mengangkut barang dari kapal sampai ke pantai. Semakin banyak anggota keluarga yang diajak, maka akan semakin mudah melakukan estafet barang dari kapal sampai ke pantai. Bila hari sedang cerah, mereka dapat menjadi penyelam, dan nelayan, hari lain mereka berdagang perolehan yang dimiliki. Ibu Elisna, warga Suku Laut Prayun menyampaikan tentang pekerjaannya sebagai berikut, "Pokoknya macam-macamlah. Mulung ya mulung, kayu bakau ya kayu bakau. Kadang cari besi. Kadang njaring ya njaring. Kapal-kapal kan membuang besi, yang nggak dipakai itu. Kalau sekarang besinya dibeli, kalau dulu ngambil ke kapal-kapal itu. Nanti dijual lagi, ada yang datang (untuk) beli" (wawancara, 3 Agustus 2016)

Lebih lanjut Ibu Elisna menyampaikan "Kalau dulu masih kecil-kecil orang tuanya nggak nyari besi, berburu sama cari kayu bakar. Baru-baru ini lah cari besi. Yang diburu celeng, monyet, biawak, untuk makan sehari-hari. Kadang ada juga orang sini yang beli." (wawancara, 3 Agustus 2016)

Mereka bekerja dengan cara bergotong royong, agar memperoleh pendapatan lebih banyak, hal ini seperti yang disampaikan oleh Ibu Elisna, "Kalau tadi kita kerja sendiri kan dapatnya kecil. Dengan dibantu sama istri, ya kerja keras suami, kadang dapat setengah kilo, istri dapat setengah kilo. Kan jadinya satu kilo. Sama-sama kita gotong royong, Pak." (wawancara, 3 Agustus 2016) 
Hal senada juga disampaikan oleh Ibu Riza Kurniati, Kabid PAUDNI Kabupaten Karimun yang menyatakan, "Mereka ini rata-rata suaminya kerjanya nyelam. Nelayan. Jadi sebetulnya pekerjaannya sama, entah nelayan, entah penyelam, entah apa. Tapi penghasilannya lebih besar daripada kita. Tabungan mereka, Pak, ditengokkan, itu dia nyimpan duitnya hampir 20 juta. Berobat aja di aja dia di Wangling, (Klinik terkenal di Tanjung Balai Karimun) Bu. Tak mau ke sini. ,Pekerjaan ibu-ibunya panggul pikul pasar, kerjanya kalau ada kapal-kapal yang di dalam masuk, bawa beras, bawa apel, Jarak dari sana ke sini, kan jauh, jadi kerjanya estafet. Kalau lagi bongkar-bongkar pasir, itu tidak bisa diganggu-ganggu itu. Anaknya mulai dari anak yang kecil sampai yang besar, semua ikut kerja. Bersusun" (wawancara, 3 Agustus 2016).

Mengikutsertakan seluruh anggota keluarga untuk bekerja, juga terdapat dalam tulisan Wasak (2012), sebagai berikut. Jumlah anggota keluarga dalam setiap keluarga nelayan di desa ini rata-rata 4 orang, yakni bapak, ibu, dan dua orang anak. Tingkat pendidikan masyarakat desa Kinabuhutan pada umumnya $(63,3 \%)$ adalah tamat dan tidak tamat SD. Hal ini disebabkan faktor lingkungan di mana anak-anak cenderung ikut ke laut daripada ke sekolah, di samping tidak adanya motivasi atau dorongan orang tua agar anak-anak mereka bersekolah lagi.

Sebagai wilayah perbatasan, warga di Kabupaten Karimun juga bekerja sebagai tenaga kerja di Negara tetangga, baik legal, maupun illegal. Ilegal di sini dapat berarti illegal yang disengaja, yaitu pergi ke luar negeri dengan paspor wisatawan atau illegal yang tidak disengaja, seperti terjadi pada nelayan, yang karena terbawa arus, di malam hari, tiba-tiba sudah memasuki perairan Negara tetangga. Pernyataan mengenai hal ini seperti disampaikan oleh Bapak Ali, "Orang Karimun ini terkenal, senang dengan uang. Kenapa? Mereka berbatasan langsung dengan luar negeri, mereka keluar masuk luar negeri, jadi semokel (smuggle, Inggris, artinya penyelundup).
Macam-macam yang dimasukkan. Nanti mereka pulang bawa elektronik. Jadi pendidikan itu nggak perlu. Karena duit dah ada. Itu yang pingin kita robah. Makanya dulu, kalau kita mau tahu yang berhasil menjadi pejabat di sini bukan orang Pulau Karimun ini. Orang Pulau Kundur, walaupun orang satu kabupaten, tapi dari pulau yang lain. Kenapa? Mereka susah. Orang susah kan mau pendidikan dulu. Kalau di sini terlena mereka, ini yang kita robah. Nyeberang langsung ke Singapur, ke Malaysia. Sekian menit sampai. Jadi tempat keluar masuk (antarnegara)" (wawancara, 1 Agustus 2016).

Lebih lanjut, mengenai nelayan, Bapak Ali mengatakan, "Mereka rata-rata berangkat ke laut malam. Mereka ini ada sistem, kalau di laut kita nggak ada ikan, mereka nyebrang ke daerah Batam. Kalau kata orang Melayu itu bertandang, Artinya nginap di sana seminggu. Jadi mereka menjaring di laut Batam. Kadangkadang mereka masuk ke perbatasan Malaysia juga, karena daerah laut Batam dengan laut Malaysia itu kan beda-beda tipis. ketidaktahuan mereka karena lalai, karena tertidur atau di tengah ngangkat jaring ini rupanya sudah masuk laut Malaysia. Ada yang langsung kalau jumpa polisi-polisi yang nggak punya tenggang rasa ya udah dihalau saja, kembali. Kalau dia (polisinya) baik, dia bilang, "udah nyebrang kalian ke seberang sana" (wawancara, 1 Agustus 2016).

Pernyataan mengenai warga Karimun yang bekerja di Malaysia disampaikan oleh Mona Indra Yuhana, sekretaris Kepala Dinas Tenaga Kerja Kabupaten Karimun, sebagai berikut. "Kalau warga Malaysia bekerja di kita pakai paspor pekerja, kalau orang kita bekerja, cukup pakai paspor pelancong, untuk masyarakat Karimun ke Malaysia hanya dengan berbekal voa saja, visa on arrival, dengan paspor pelancong itu tidak bermasalah, no problem. karena mereka ada hubungan keluarga, karena di sana ada pak ciknya sehingga tidak dikejar polis, yang permasalahan di kami adalah karena karimun ini adalah daerah perbatasan, semua dari Jawa darimana, datangnya ke Karimun dengan kapal 
ferry. maka nampak TKI turun, lalu ada PPTKI yang menampung. Kadang ada yang legal, illegal, resmi, tak resmi. sehari dapat RM60, RM 70, kadang RM210/hari, kalau kepala masak RM100 lebih, tapi mereka dapat tujuh hari pulang, nanti mereka bikin paspor lagi, sebulan baru bisa berangkat. yang kalau dirupiahkan sekitar Rp200.000/hari, karena kami daerah perbatasan, semua berangkat dari sini, jaraknya hanya 45 menit sudah sampai. PP Cuma Rp250.000,-. Mamanya masuk, mamanya pulang, nanti bapaknya lagi kerja, bapaknya pulang, nanti anaknya lagi kerja bekerja, papanya masuk bekerja, anaknya masuk bekerja lagi. Tidak benar mereka ke Malaysia membawa rokok, kecuali para penyelundup. Yang bawa-bawa rokok itu jaman dulu, kita tahu hukuman di Malaysia itu ketat sangat, jadi tidak benar kalau mereka bawa rokok." (wawancara tanggal 5 Agustus 2016).

Pekerjaan warga perbatasan semacam ini juga ditemukan pada tulisan Abdullah dan Permata Sari (2014) di Badau, Kapuas Hulu, sebagai berikut. "Penduduk Badau memenuhi kebutuhan pekerjaan dengan bekerja di perkebunan yang ada di wilayah Indonesia dan menjadi tenaga kerja perkebunan di wilayah Malaysia. Sebagian juga terlibat sebagai pedagang yang membawa barang-barang ke Malaysia. Bekerja di Malaysia lebih memiliki daya tarik karena penghasilan lebih besar dibandingkan bekerja di negeri sendiri.Dalam satu hari, para buruh bisa mendapatkan upah hingga RM 50 sehingga mereka bisa meraih upah 2.000 RM dalam satu bulan. Dengan nilai tukar RM 1 sama dengan Rp 3.250, maka bekerja di Malaysia akan mendapatkan penghasilan Rp 6.500.000. Jika bekerja sebagai buruh harian di Indonesia, mereka hanya mendapatkan gaji Rp 50.000 perhari atau hanya Rp 1.500.000 perbulan. Perbedaan jumlah pendapatan yang cukup tinggi inilah yang menjadi daya tarik warga Badau bekerja di Malaysia.Pemerintah Malaysia membutuhkan tenaga kerja dari Indonesia untuk "pekerjaan kasar" karena Malaysia kekurangan tenaga kerja untuk perkebunan karet dan sawit. Sebagian besar mereka adalah buruh ilegal yang tidak dilengkapi dengan dokumen resmi dan ijin kerja" (2014:232)

\section{Persepsi Masyarakat terhadap Pendidikan}

Berdasarkan data statistik Kabupaten Karimun, diketahui jumlah penduduk usia 5-19 tahun sebesar 66.771 orang, sementara penduduk yang bersekolah dari tingkat SD-SMA, pada saat yang sama berjumlah 53.988 orang. Artinya $19 \%$ jumlah penduduk usia tersebut tidak bersekolah (data diolah dari Karimun dalam Angka tahun 2016, Republik Indonesia, 2016). Berdasarkan jumlah sekolah di tiap jenjang pendidikan, diketahui, terdapat 148 SD/MI, 60 SMP sederajat, 18 SMA, 5 MA, dan 8 SMK (Republik Indonesia, 2016).

Bila melihat kondisi masyarakat di Kabupaten Karimun, termasuk pekerjaannya, maka diidentifikasi alasan mereka tidak bersekolah, adalah karena tidak adanya kesadaran akan pentingnya pendidikan, yang sudah terjadi secara turun-temurun. Alasan ini salah satunya disampaikan oleh Bapak Raja "Mereka berfikir pendidikan itu tidak memberikan dampak. Tapi ketika bekerja, hari ini mereka bekerja, besok dapat duit, hari ini dapat duit. Di sini kan hanya ada 2 dua jenis perusahaan. Pertama seperti outsourcing. Yang kedua, tambang. Kalau tambang butuh apa dia, operator, sopir. Pandai nyopir udah. Nggak perlu pendidikan. Orang Karimun ini terkenal, senang dengan uang. Kenapa? Mereka berbatasan langsung dengan luar negeri, mereka keluar masuk luar negeri, jadi semokel (smuggle, Inggris, artinya penyelundup). Macam-macam yang dimasukkan. Nanti mereka pulang bawa elektronik. Jadi pendidikan itu nggak perlu. Karena duit dah ada. Itu yang pingin kita robah. Makanya dulu, kalau kita mau tahu yang berhasil menjadi pejabat di sini bukan orang Pulau Karimun ini. Orang Pulau Kundur, walaupun orang satu kabupaten, tapi dari pulau yang lain. Kenapa? Mereka susah. Orang susah kan mau pendidikan dulu. Kalau di sini terlena mereka, ini yang kita robah. 
Nyeberang langsung ke Singapur, ke Malaysia. Sekian menit sampai. Jadi tempat keluar masuk (antar Negara) " (wawancara, 1 Agustus 2016).

Jawaban ini dikuatkan oleh wawancara dengan Kepala Dinas Pendidikan Kabupaten Karimun, yaitu: "Mereka ngerti Bahasa Indonesia. Mereka kuasai Bahasa Indonesia. Walaupun mereka tidak sekolah, orang tuanya apa, tapi mereka paham. Ngitung uang paham. Paham uang seribu, seratus juta. Ini berapa harganya, tahu dia. Matematik hebat dia daripada mereka dari kita. Dagangnya mantap. Walaupun suku-suku laut, tapi mereka sudah punya mobil. Nah, itu. Pergi cari ikan, makan. rumah, bisa beli ini. Itu aja pikiran mereka sekitar situ aja." (wawancara, 1 Agustus 2016)

Ketika ditanya, mengenai perhatian orang tuanya terhadap pendidikan anak, Kepala Bidang Keaksaraan menyampaikan: "Putus sekolah karena memang dari si anak itu tidak mau sekolah dan perhatiannya pun kurang dari orang tua. Biasanya seperti itu, orang tuanya tidak mendukung, mau berhenti, dia pun orang tuanya mendukung berhenti." (wawancara, 31 Juli 2016)

Anggapan bahwa pendidikan tidak memberi dampak yang berarti bagi kehidupan sangat dipengaruhi oleh pandangan lingkungannya, terutama orang tua, sehingga walaupun pemerintah sudah melakukan berbagai usaha untuk memotivasi bersekolah, banyak yang gagal. Pernyataan ini disampaikan oleh Mona Indra Yuhana, sekretaris Kepala Dinas Tenaga Kerja Kabupaten Karimun. "Kalau orang sini Paket A, Paket B, Paket $C$ mereka gak perhatian yah begitulah tergantung lingkungannya, tergantung orang tuanya. Kalau mereka lepas SD bekerja di Malaysia, Sebenarnya kalau mereka tu dah sekolah, di Malaysia mereka tu sudah ada jati diri. Usaha pemerintah Dinas Pendidikan pun sudah macam-macam, ada sekolah satu atap atau sudah menggiat. Cuma itu memang sudah pola pikir dan beban perilaku masyarakat itu Merupakan kebanggaan bagi mereka kerja di Malaysia, walaupun jadi kuli kasar di sana." (wawancara tanggal 5 Agustus 2016)

Aspirasi orangtua terhadap pendidikan anak mempunyai peran yang besar. Hal ini sesuai dengan pernyataan Setyawati (2015), bahwa aspirasi orangtua terhadap pendidikan anak sangat tinggi, ditunjukkan pada aspirasi yang positif tentang pendidikan, orangtua memberikan dorongan atau motivasi sebagai bentuk perhatian kepada anak, orangtua berharap anak dapat mengenyam pendidikan setinggi mungkin, dan setelah lulus mendapatkan pekerjaan yang layak.

Pernyataan Setyawati ini sesuai untuk diterapkan di Kabupaten Karimun. Artinya, jika untuk memperoleh pekerjaan dengan penghasilan yang besar di Kabupaten Karimun seseorang tidak perlu mengecap pendidikan tinggi, maka wajar saja bila mereka kemudian mempunyai persepsi untuk apa mereka harus bersekolah tinggi. Padahal, waktu bersekolah dapat dipakai untuk membantu kedua orangtuanya bekerja serta memperoleh tambahan penghasilan.

Anak yang tidak mempunyai motivasi bersekolah, biasa ditandai dengan datang terlambat, dan sering tidak masuk, terlebih karena orang tua juga tidak bersekolah. Hal semacam ini disampaikan oleh Kabid Keaksaraan Kabupaten Karimun, "Banyak yang malas sekolah gitu lah, memang tak ada kemauan dari dia buat sekolah; yang pertama dia sering lambat, yang kedua tak masuk. Itu dah menandakan. Apalagi di rumah kurang perhatian dari orang tua, latar belakang pendidikan orang tua nol. Kadang kadang orang tua tak sekolah" (wawancara, 31 Juli 2016)

Pernyataan yang sama juga berasal dari Kepala Dinas Pendidikan Kabupaten Karimun menyatakan, "Ada sebagian orang tua yang ngerti, rata-rata mereka ada anak yang sekolah, sarjana juga ada. Hanya anak-anak itu dengan orang tuanya itu sendiri yang minta ke laut. Tak serius aja ke sekolah. Itu yang susah. Mereka mau belajar paket itu udah 
lumayan bagi kita. Itu pun dikejar-kejar. Ujian dicari-cari. sedangkan orang tua sendiri itu nggak mensupport. Karena orang tua dulu ratarata nggak sekolah, susah. Orang tua buta huruf Nggak bisa baca, dan mereka bisa membuktikan dengan buta huruf tetap kaya. Pergi cari ikan, makan bisa, rumah bisa beli" (wawancara, 1 Agustus 2016).

Untuk mengatasi masalah anak yang sering datang terlambat dan tidak masuk, pihak sekolah sudah berusaha untuk memotivasi siswa kembali ke sekolah. Pernyataan seperti ini seperti sampaikan oleh Kepala Bidang Keaksaraan Kantor Dinas Pendidikan Karimun, "Pihak sekolah sudah berusaha mendatangi rumah. Kan kita ada sistemnya di sekolah. Lihat anak ini sekali tak masuk, dua kali tak masuk, seperti apa, nanti ada kunjungan ni guru BP ke rumah. Dilihat, dicari anak-anak ni pada kemana tak masuk sekolah gitu kan. Buat surat panggilan, orang tua datang. Kadang kadang orang tua yang diundang tidak datang makanya gurugurunya kepikiran kok tidak mau sekolah. Nah usaha - usaha sekolah kita sudah seperti itu." (wawancara, 31 Juli 2016).

\section{Peran PKBM dalam Mengurangi Buta Aksara di Kabupaten Karimun}

Untuk menjaring warga masyarakat usia 15-59 tahun yang tidak atau belum sempat mengecap pendidikan formal, pemerintah melalui Pendidikan Nonformal Kabupaten Karimun pada tahun 2014 menyelenggarakan 22 PKBM, dengan program KB/PAUD, Kesetaraan Fungsional, Kesetaraan Usaha Mandiri, Paket A, Paket B, dan Paket C. Adapun jumlah tutor dan warga belajarnya dapat dilihat pada Tabel 2 .

Berdasarkan tabel tersebut juga terlihat bahwa peran PKBM sangat penting dalam mengurangi buta aksara di Kabupaten Karimun, dari 22 PKBM yang ada di Kabupaten Karimun, Program Keaksaraan Fungsional mempunyai peminat tertinggi, mencapai 773 warga belajar, diikuti oleh KB/PAUD sebanyak 643 anak, Paket B sebanyak 525 orang, Paket $C$ sebanyak 306orang, Paket A sebesar 199 warga belajar,
Keaksaraan Usaha Mandiri sebanyak 88 orang. Sedangkan program Keaksaraan Dasar saat ini tidak ada peserta didiknya.

Manfaat pelaksanaan Program Keaksaraan Fungsional, terdapat dalam salah satu wawancara pada tulisan Bawani dan Fauziyah (2014) yaitu: "Terselenggranya program Keaksraan Fungsional ini sangat bermanfaat sekali bagi warga buta aksara di dusun petissari supaya masyarakat paham betapa pentingnya mempunyai kemampuan membaca, menulis dan berhitung dalam kehidupan mereka seharihari dan setelah mengikuti program ini warga belajar juga bisa mengembangkan kemampuan yang telah dimilikinya dalam kehidupan bermasyrakat berbangsa dan bernegara."

Di awal pelaksanaan PKBM, dalam menjaring warga belajar, Dinas Pendidikan Nonformal informal melakukan pendataan warga buta aksara, dengan menggunakan kartu yang ada tulisannya, hal itu diungkapkan oleh Ibu Siti Muawanah, Kepala Seksi Pendidikan Kesetaraan dan Kemasyarakatan Dinas Pendidikan Kabupaten Karimun "Mereka malu kalau ketahuan meraka tak pandai membaca, kalau ditanya langsung dia bohong itu. Jadi sambil pendataan sambil ngobrol-ngobrol kita bawalah itu kartu yang ada tulisannya. Kalau dia pegang pun terbalik, ketahuan kalau dia tak pandai membaca, kita ajaklah dia untuk ikut belajar di PKBM." (wawancara, 31 Juli 2016).

Hal senada disampaikan oleh Bapak Razali Zulkifli, ketua PKBM Mitra Mandiri Karimun, menyatakan, Kami PAUDNI mendata by name, by address, caranya kita bertamu, sambil tunjukkan kartu yang ada tulisannya. Kalau mereka tak dapat membaca, maka kita ajak dia untuk ikut belajar di PKBM." (wawancara, 3 Agustus 2016).

Selain pendataan, pemberian motivasi mengikuti PKBM juga dilakukan oleh Dinas Pendidikan Nonformal Informal yang merangkap menjadi Ketua PKBM Mitra Mandiri Karimun, Bapak Razali Zulkifli, menyatakan, "Saya bilang aja, kalian mana tahu suatu waktu perlu ijazah ini, perlu apa, perlu SMP ini. Perlu ijazah ini 


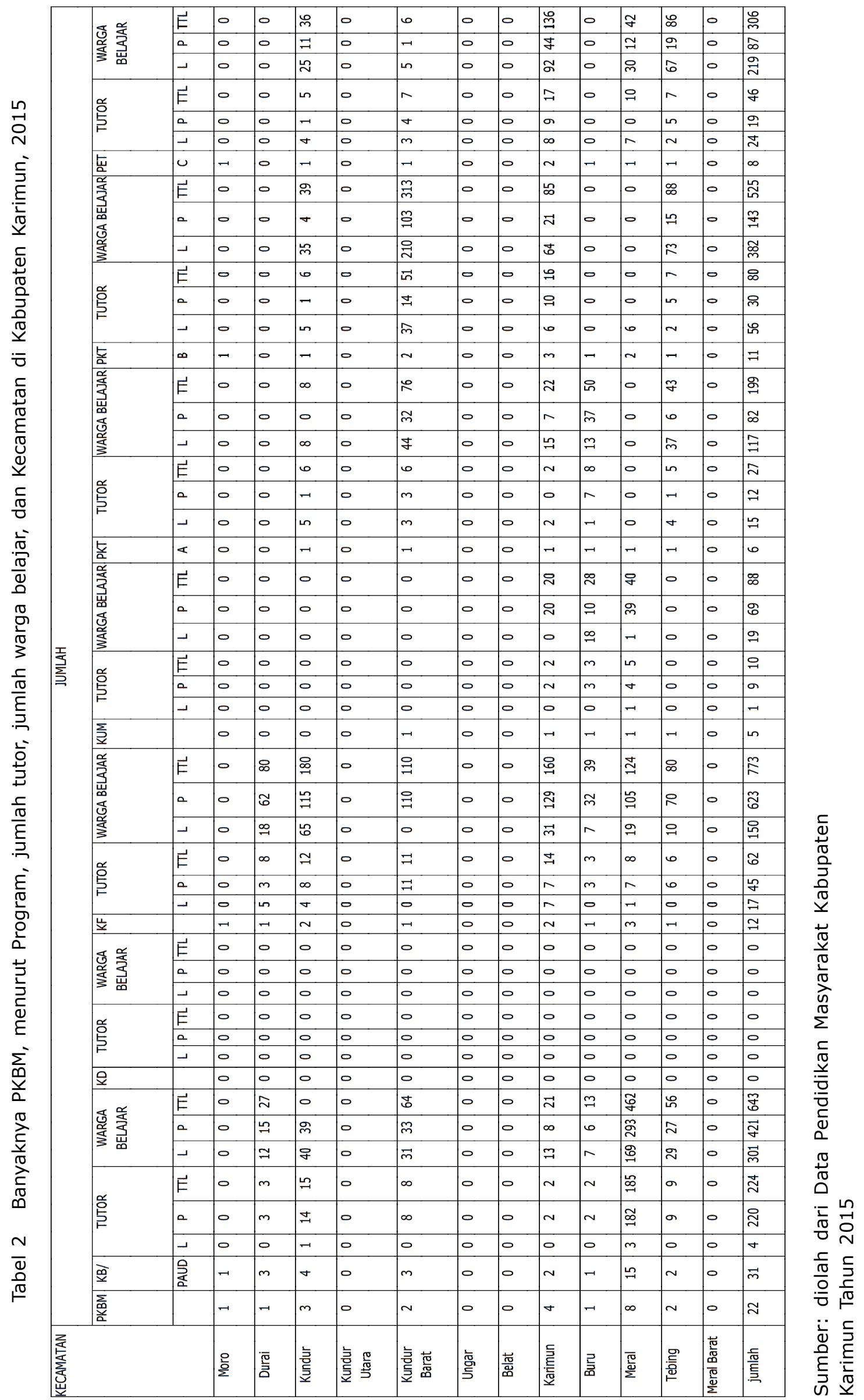


untuk buat buat apa. Kalau perlu apa. Mungkin nanti nak buat pasport tiba-tiba tak berlaku lagi ijazah SD, mana tahulah kita 5 tahun kedepan, 10 tahun ke depan." (wawancara, 3 Agustus 2016).

Ibu Siti Muawanah menyatakan, ada juga tutor yang memotivasi warga untuk ikut belajar dengan cara yang tidak biasa, "Kalau malam biasa bapak-bapak itu berkumpul di pos ronda, sambil ngobrol-ngobrol dan main kartu. Suatu saat tutor ini datang, minta ikut main. Maka mainlah mereka, dan tutor ini menang, maka uangnya dia traktir orang ramai makan-makan. Besok barang berapa hari pak ini tak datangdatang. Suatu saat datang lagi dia, main lagi, menang lagi, dia traktir lagi orang-orang itu. Begitu terus caranya, sampai warga di situ bertanya, Pak itu siapa namanya, kenapa bisa menang terus. Lalu pak itu menjawab, ya laah saya pintar ni karena saya bersekolah. Kalau kau mau pintar, ikutlah bersekolah." (wawancara, 31 Juli 2016)

Penanggungjawab PKBM perlu memberikan motivasi kepada warga belajarnya, juga terlihat pada wawancara penelitian yang dilakukan oleh Ibu Titi Rumiyati dalam Rusikawati (2010:83), sebagai berikut: "kami berusaha memotivasi kesadaran warga belajar masyarakat disini dengan cara memberikan sisipan ketrampilan pada materi belajar mereka. Karena seperti latar belakang kehidupan mereka yang untuk makan saja sulit, apalagi untuk belajar, mereka itu selalu mencari dan mencari bagaimana supaya tetap bisa makan dan hidup, jadi dengan dibekali dengan ketrampilan nantinya bisa dijadikan usaha tambahan bagi mereka." (wawancara, 19 Januari 2010).

Seluruh pengelola PKBM di Kabupaten Karimun merupakan Pegawai Negeri Sipil Dinas Pendidikan Kabupaten Karimun, yang mempunyai jabatan sebagai Kepala Sekolah SD dan SMP, dan dibantu oleh beberapa tenaga honorer. Pemilihan Kepala Sekolah SD dan SMP sebagai Pengelola PKBM dimaksudkan untuk mempermudah jalur koordinasi dengan Dinas Pendidikan Karimun, termasuk urusan tahapan pengang- garan keuangan yang diperoleh melalui Kantor Dinas Pendidikan Karimun.

Anggaran keuangan PKBM selain diperoleh dari Pusat, juga berasal dari iuran warga belajar PKBM, serta unit usaha yang dilakukan oleh beberapa PKBM. Ada beberapa program kewirausahaan yang dilakukan oleh PKBM di Karimun, seperti budi daya lele, bertanam cabe, selada, dan pisang kapok.

Salah satu unit usaha yang dilakukan oleh PKBM Bakti Negeri, adalah Kantin Cik Mungil, yang menyajikan laksa sebagai menu andalannya, dengan harga Rp 10.000,- per porsi. Namun, digratiskan bagi tutor yang mengajar di PKBM ini. Laksa adalah makanan berbentuk mie yang terbuat dari sagu, yang pohonnya ditanam di belakang PKBM Bakti Negeri, merupakan milik orang tua pengelola PKBM Bakti Negeri.

Terdapat beberapa motivasi warga belajar yang sudah mengikuti Pendidikan Keaksaraan dan Kesetaraan antara lain adalah kepentingan politis, dan untuk kepentingan kenaikan gaji di tempat mereka bekerja. Mengenai kepentingan politis, disampaikan oleh Rahmat dari PKBM Al Himmah, "Wah pernah ada (warga belajar) yang (berusia) 80 tahun, Bu. Kemaren ceritanya dia tuh mau nyalon jadi kades, semangat ikut. Udah tua. Terus nggak jadi kades, Ya berhenti. Sekarang ini ada murid kita satu lagi. Kades. Jadi sekarang udah jadi kades, saya nengok pake ijazah SMP. 'Saya ikut Paket C, masuklah saya." (wawancara, 4 Agustus 2016).

Untuk kepentingan kenaikan gaji, disampaikan oleh Rahmat dari PKBM Al Himmah, "Biasanya orang-orang yang ikut program kesetaraan bekerja di perusahaan-perusahaan, di sini kan deket PT. Ada 3 PT galangan kapal, jadi rata-rata mereka butuh naik pangkat. Ijazahnya SMA Yang BIP aja kemari ada 6 orang. BIP itu yang rata-rata umurnya sudah 52 karena tinggal 3 tahun lagi pensiun tertarik menempuh pendidikan (kesetaraan). Kalau disuruh sekolah aja, Bu, tak diiming-imingi pangkat mungkin ndak mau juga orang-orang itu. Untuk apa sekolah" (wawancara, 4 Agustus 2016). 
Ada juga warga belajar di Kelurahan Moro, Kecamatan Moro dan kelurahan Alay, Kecamatan Kundur, yang berusia 60 tahun, yang tetap menjadi warga belajar di PKBM dengan maksud untuk memotivasi orang-orang yang lebih muda, agar tetap semangat belajar.

Selain adanya perbedaan antara keinginan anak dan dukungan orang tua agar anaknya sekolah dan orang dewasa ikut PKBM, ada juga faktor lain yang menjadi penyemangat, yaitu waktu belajar di PKBM yang dianggap lebih fleksibel bila dibandingkan dengan waktu belajar di sekolah. Mengenai waktu belajar di PKBM, Rahmat dari PKBM Al Himmah menyampaikan, "Jam belajar habis Isya", jam 7 lewat, atau jam 8 sampai jam 9.15, seminggu dua kali. Kita kasih tugas kadang bu. Kita kasih modul, kalau nanti pas datang 2 minggu sekali, langsung tes. Gimana pelajaran mereka. Nanti semesteran tetap ada. Semester satu, semester dua kita tetap ada. Untuk hari-harinya itulah nanti kalau memang yang hadir kita tetap, tutor tetap hadir terus. Walaupun 2-3 orang ya tetap kita ajar. Tapi ya sistemnya ya seperti itu. Yang tak hadir ya, namanya orang tua kadang-kadang lupa. Ujian aja dijemput. Sampai sms satu-satu untuk masuk ujian. Kadangkadang kan lupa." (wawancara, 4 Agustus 2016).

Waktu yang dianggap cukup fleksibel ini pun tidak dapat membuat semua warga belajar datang semua di setiap hari belajarnya, karena faktor pekerjaan. Misalnya untuk untuk pekerja pabrik. Bapak Zulkifli menyatakan, "Kalau yang namanya di PT ini kerjanya shift. "Shift ini kan saya masuk malam, Pak", kalau mau ikutkan shift mereka. Kawan-kawan yang lain pun ikut, kenapa, karena mereka lain-lain shift. Ada yang masuk siang, ada yang masuk malam. Apakah kita harus masuk siang, masuk malam? Emang gaji tutor berapa? Pokoknya mereka kalau nggak sampai $70 \%$ mereka masuk, mereka nggak kita ikutkan ujian. Lha kalau shift kan biasanya shift seminggu pagi, seminggu sore. Nah begitu minggu ini mereka bisa datang, minggu besok tidak datang. Itu sudah pasti. Kita rata-rata sudah menyampaikan kalau dapat tiga shift itu, jam masuk jadwal. Biasanya mereka bisa berubah. Bisa change, dalam arti kata, kalau yang ini masuk shift mereka, mereka ganti. (bertukar jadwal dengan temannya)". (wawancara, 3 Agustus 2016).

Bagi para nelayan, belajar mereka juga ikut musim berlayar, lebih lanjut Bapak Zulkifli menyatakan, "Misalnya musim utara yang angin kuat itu tidak ke laut, jadi kita padatkan kegiatan. Mungkin seminggu empat kali." (wawancara, 3 Agustus 2016).

Perbedaan waktu belajar tiap orang dalam masing-masing PKBM tidak kemudian menyurutkan semangat pengelola PKBM dan warga belajar untuk tetap menjalankan kegiatan belajar-mengajar di Kabupaten Karimun. Intinya adalah musyawarah bersama antara pengelola, tutor, dan warga belajar.

Selain pengelola PKBM yang kesemuanya merupakan pegawai negeri sipil, di PKBM juga terdapat tutor yang tugasnya mengajar warga PKBM sesuai dengan programnya. Tidak semua tutor merupakan pegawai negeri, sehingga dapat diikutkan dalam kegiatan Dinas Pendidikan Kabupaten Karimun. Oleh karena itu tutor ini perlu dibayar honornya. Bapak Razali Zulkifli menyatakan, "PKBM saya itu meng-ambilkan pegawai negeri karena saya berfikir kita dapat dana atau tidak kita kan belum tahu. Paket B itu gratis, Pak. Nggak bayar, yang penting mereka mau ikut. Kita panggilkan kawan-kawan guru SMP, guru SMA yang sudah punya sertifikasi, dapat dana sertifikasi, dapat dana sebagai pegawai. Jadi inilah kita di pulau sebagai salah satu bentuk pengabdian kita kepada masyarakat. Itu salah satu motivasi saya agar mereka mau mengajar. Syukur-syukur kalau ada dana nanti kita bantu sekadar, kalau kata orang Melayu, kalo ngrokok yang uang rokok. Kalau tidak ya uang apalah gitu. Jadi kalau kami betul-betul, lillahi ta'ala." (wawancara, 3 Agustus 2016).

\section{Hambatan Pelaksanaan Belajar-Mengajar PKBM di Kabupaten Karimun}

Dalam melaksanakan belajar-mengajar di PKBM, 
terdapat beberapa hambatan, misalnya pada penyesuaian antara jam kerja dan jam belajar warga belajar, jauh dan sulitnya jarak tempuh, keterbatasan jumlah tutor dan besar honor tutor, menyebabkan proses belajar mengajar tidak cukup lancar.

Walaupun untuk menetapkan jam belajar, telah dilakukan musyawarah antara pengelola, tutor, dan warga belajar. Namun, warga belajar yang bekerja sebagai buruh pabrik, mempunyai jam kerja shift, kadang memperoleh kesempatan untuk tukar shift dengan temannya, dan ada kalanya tidak dapat bertukar shift sehingga tidak dapat hadir ke PKBM.

Jarak tempuh yang jauh juga menyebabkan warga belajar dan tutor kadang tidak hadir. Alat transportasi yang biasa mereka pakai adalah kendaraan roda dua. Bila sedang hujan atau tidak ada bensin, mereka juga lalu tidak hadir.

Honor tutor PKBM dapat berasal dari dana operasional pusat, dapat juga dari iuran warga PKBM, dan atau dari unit usaha yang dimiliki oleh masing-masing PKBM, yang penerimaan PKBM tiap bulan tidak tentu jumlahnya. Menurut Bapak Kipi, "Mungkin dari peserta umpama terdaftar 20, itu 10 yang bayar. Biasanya bagi yang mengambil ijazah, diharuskan membayar. Tapi itu pun tidak dapat diharapkan (wawancara, 3 Agustus 2016). Lebih lanjut Bapak Kipi menyatakan, "Kita cuma berani bayar tutor Rp 250.000,- Ini mereka disuruh masuk minimal 2 kali dalam satu minggu. Mereka itu datang pakai motor. Kadang-kadang 6 bulan, belum kita bayar gaji mereka. Kalau mengharapkan dari bayaran sampai sekarang itu yang tamat tahun 2015 dari 47 orang untuk Paket C, baru 6 orang yang mengambil ijazah, karena mereka belum bayar. Sekarang ini bayaran Paket C Rp 100.000,-. Sebulan, karena mereka pekerja. Kalau yang tak mampu, tidak membayar" (wawancara, 3 Agustus 2016).

Berkaitan dengan jauhnya jarak tempuh dan besar honor tutor ini menyebabkan PKBM di Kabupaten Karimun mempunyai jumlah tutor yang terbatas. Hal ini menyebabkan proses belajar mengajar tidak cukup lancar. Misalnya, tutor datang tanpa membuat persiapan mengajar dan berpedoman pada buku formal. Harapannya adalah Pemerintah membuat modul pembelajaran seperti di Universitas Terbuka, agar warga belajar dapat belajar sendiri, kemudian mengkonsultasikan kesulitannya pada waktu tutorial, sehingga tutor tidak perlu sering datang seperti di sekolah formal. Pernyataan ini disampaikan oleh Bapak Kipi, "Kita keterbatasan SDM tutor. Jadi kita masih menggunakan tutor-tutor dari guru formal. Sehingga kita merasakan itu tidak efektif, karena mereka kadang datang mengajar tanpa membuat persiapan, seharusnya mereka membuat rencana pembelajaran. Artinya mereka datang, berpedoman pada pendidikan formal. Kita sangat berharap pemerintah pusat menerbitkan, modul, seperti UT itu. UT itu Iho satu semester cuma 8 kali pertemuan, mereka ujian. Tapi modul mereka betul-betul bisa dipertanggungjawabkan. Nah kita pengennya seperti itu. Mereka kan tutor, tutorial. Kan artinya kalau mereka punya modul. Ketika warga belajar kita ada kendala, baru konsultasi, kan begitu. Kalau tutorial itu berapa jam tatap mukanya. Kalau sekarang kita dituntut sekian jam tatap muka. Kalau begitu namanya bukan tutor, tapi guru. Jadi kita menggaji guru pun harus standar. Kalau sekarang, apa dengan gaji 200 cukup? Karena sifatnya tutorial, mungkin satu kali satu minggu mereka masuk, atau pun setengah bulan sekali mereka baru tatap muka, itu baru sesuai" (wawancara, 3 Agustus 2016).

Hambatan-hambatan di atas juga dituliskan oleh Sihombing dalam Fatimah (2008), antara lain adalah: 1) Perkembangan program belum diimbangi jumlah dan mutu tenaga yang memadai, 2) Ratio modul untuk warga belajar program kesetaraan (Paket A, B, dan C) jauh dari mencukupi, 3) Tidak ada tempat belajar yang pasti, 4) Kualitas hasil pembelajaran sulit dilihat kebenarannya dan sulit diukur tingkat keberhasilannya, 5) Lemahnya akurasi data atau info tentang sasaran program, 6) Jadwal pelaksanaan belajar mengajar yang tidak selalu dapat dilaksanakan tepat waktu. 


\section{SIMPULAN DAN SARAN}

\section{Simpulan}

Berdasarkan penelitian mengenai peran PKBM dalam mengurangi buta aksara di Kabupaten Karimun, dapat disimpulkan sebagai berikut.

Pertama, pekerjaan penduduk Kabupaten Karimun beragam, mulai dari nelayan, petani, berburu, kuli panggul pelabuhan, pekerja di pabrik-pabrik yang banyak terdapat di Pulau Karimun; pemulung, pedagang, ada juga menjadi TKI, baik legal maupun illegal. Pekerjaan semacam ini tidak menuntut pendidikan sebagai syarat untuk diterima bekerja. Selain pekerjaan tersebut masih ada pekerjaan lain, seperti PNS.

Para pekerja biasa menggunakan motor sebagai sarana transportasi menuju ke tempat kerja, karena tidak semua tempat di Kabupaten Karimun terdapat transportasi umum. Apa bila seseorang biasa melakukan commuter antar pulau, maka dia akan mempunyai dua buah motor di kedua pulau yang sering dikunjunginya. Motor tersebut kemudian dititipkan di pelabuhan yang dia tinggalkan.

Kedua, masyarakat mempunyai kesadaran yang rendah terhadap pentingnya pendidikan, mengingat tanpa bersekolah pun mereka dapat memperoleh penghasilan yang besar dari pekerjaan yang dia jalani.

Ada pekerjaan yang menuntut tenaga kerja banyak, seperti menjadi kuli panggul pikul, yang akan mengangkut barang dari kapal sampai ke pantai, ketika ada kapal bongkar muatan. Semakin banyak anggota keluarga yang bekerja, akan semakin panjang peserta estafet pengangkutan barang menuju ke pantai. Pekerjaan semacam ini membuat mereka merasa bekerja lebih penting daripada sekolah. Pekerjaan menjadi TKI dengan menggunakan paspor pelancong juga diminati oleh masyarakat di Kabupaten Karimun.

Ketiga, peran PKBM sangat penting dalam mengurangi buta aksara di Kabupaten Karimun, dari 22 PKBM yang ada di Kabupaten Karimun, Program Keaksaraan Fungsional mempunyai peminat tertinggi, mencapai 773 warga belajar, diikuti oleh KB/PAUD sebanyak 643 anak, Paket
B sebanyak 525 orang, Paket C sebanyak 306 orang, Paket A sebesar 199 warga belajar, Keaksaraan Usaha Mandiri sebanyak 88 orang.

Berbeda dengan kesadaran untuk bersekolah, keinginan masyarakat mengikuti kegiatan di PKBM adalah untuk kepentingan politik atau untuk kenaikan gaji di tempatnya bekerja.

Ada orang yang ikut program kesetaraan karena ingin mencalonkan diri menjadi kepala desa, begitu dia gagal, maka dia keluar dari PKBM. Ada juga orang yang mau pension ikut belajar di PKBM, karena ingin menaikkan gajinya. Belajar di PKBM dianggap lebih fleksibel dalam soal waktu belajar dibandingkan belajar di sekolah formal.

Keempat, dalam pelaksanaan PKBM ini terdapat beberapa hambatan, antara lain jam kerja warga belajar, jauh dan sulitnya jarak tempuh, keterbatasan jumlah tutor dan besar honor tutor

\section{Saran}

Masih banyak masyarakat di Kabupaten Karimun beranggapan bahwa tujuan sekolah adalah untuk memperoleh pekerjaan dan upah yang lebih baik dibandingkan dengan mereka yang tidak bersekolah, dan ini tidak terjadi di Kabupaten Karimun, maka sebaiknya Bidang Pendidikan Nonformal Informal Dinas Pendidikan melakukan:

1) Kerja sama dengan dinas lain, misalnya Dinas Kesehatan, Dinas Sosial, Dinas Pertanian, Pangan, dan Perikanan untuk kegiatan bakti masyarakat, agar dapat menggugah kesadaran masyarakat mengenai manfaat menjadi pintar, yang bersifat immateri. Misalnya dapat membaca resep masakan, mengetahui macam-macam obat tradisional yang bermanfaat.

2) Menyediakan Taman Bacaan Masyarakat di tempat umum, seperti Puskesmas, Pelabuhan, dengan buku-buku dan tabloid sederhana yang diminati masyarakat. 
Ucapan terima kasih penulis sampaikan kepada peneliti Subijanto yang telah dengan tekun membimbing, mengarahkan, dan memberi masukan yang konstruktif dalam proses penulisan karya tulis ilmiah ini.

\section{PUSTAKA ACUAN}

Abdullah \& Sari P, Intan. 2014. Politik Identitas Masyarakat Perbatasan Indonesia-Malaysia: Kasus Badau di Kapuas Hulu, Kalimantan Barat (232). Kawistara 4(3), 225-236, https:// jurnal.ugm.ac.id/ kawistara/article/ viewFile /6378/5036, diakses tanggal 7 Maret 2017.

Bawani \& Fauziyah. 2014. Pengelolaan Program Keaksaraan Fungsional Untuk Memberantas Buta Aksara di Petissari, Babaksari, Dukun, Gresik. Jurnal Kependidikan Islam, 4 (1) http:// jurnalki.uinsby.ac.id/index.php/jurnalki/article/view/11 diakses tanggal 25 Maret 2017

Defriana, W. 2015. Efektivitas Pusat Kegiatan Belajar Masyarakat (PKBM) Sejahtera di Kelurahan Parit Mayor Kecamatan Pontianak Timur. Jurnal S1-IImu Administrasi Negara, 4(2), 1-22 http://docplayer.info/41330904-Efektivitas-pusat-kegiatan-belajar-masyarakat-pkbmsejahtera-di-kelurahan-parit-mayor-kecamatan-pontianak-timur.html, diakses tanggal 30 Maret 2017

Fatimah. 2008. Peranan Pusat Kegiatan Belajar Masyarakat (PKBM) dalam rangka Pengembangan Masyarakat (Studi Kasus: Program Paket C pada PKBM Santika, Kelurahan Bambu Apus, Kecamatan Cipayung, Kotamadya Jakarta Timur, Provinsi DKI Jakarta). Skripsi, Institut Pertanian Bogor. https://core.ac.uk/download/ pdf/32339594.pdf, diakses tanggal 26 April 2017

Hartini, Sumarno, \& Hiryanto. 2015. Dampak Pendidikan Keaksaraan terhadap Tingkat Sosial Ekonomi Keluarga. http://journal.uny.ac.id/index.php/diklus/article/download/3586, (173179), diakses tanggal 29 Maret 2017

Hiryanto. 2008. Pemberdayaan Masyarakat Melalui Pendidikan Nonformal, http://staff.uny.ac.id/ sites/default/files/tmp/makalah-ppm-pemberdayaan-masyakat-pnf.pdf. disampaikan dalam Lokakarya Pemberdayaan Masyarakat dalam Pendidikan Luar Sekolah tanggal 22 November 2008 di Badan Perencanaan Pembangunan Daerah (Bappeda) Kabupaten Bantul. diakses tanggal 7 Maret 2017

Republik Indonesia. 2003. Undang-Undang Republik Indonesia Nomor 20 Tahun 2003 tentang Sistem Pendidikan Nasional.

Republik Indonesia. 2016. Karimun Dalam Angka Tahun 2016. Karimun: Badan Pusat Statistik Kabupaten Karimun

Republik Indonesia. 2015. Rencana Strategis Kementerian Pendidikan dan Kebudayaan 20152019. Jakarta: Kementerian Pendidikan dan Kebudayaan

Rusikawati. 2010 Efektivitas Pusat Kegiatan Belajar Masyarakat (PKBM) Usaha Mulya dalam Meningkatkan Pendidikan Masyarakat di Kecamatan Cangkringan Kabupaten Sleman. Skripsi, Surakarta: Universitas Sebelas Maret. https://eprints.uns.a c.id/5528/1/Unlockg.pdf. diakses tanggal 26 Maret 2017.

Rizqi, M. 2008. Peran PKBM Suka Caturtunggal Dalam Peningkatan Sumber Daya Manusia di Kelurahan Caturtunggal, Depok, Sleman, Yogyakarta. Skripsi, Yogyakarta: UIN Sunan Kalijaga http://digilib.uin-suka.ac.id/927/ diakses tanggal 29 Maret 2017. 
Sari. 2014. Analisis Efektivitas Pengelolaan Pusat Kegiatan Pembelajaran Masyarakat (PKBM) (Studi Evaluatif di PKBM Sriwijaya Sawah Lebar Kota Bengkulu). Tesis. Universitas Bengkulu. http://repository. unib.ac.id/8454/ diakses tanggal 29 Maret 2017

Saepudin, Sadikin, \& Saripah. 2016. Penguatan Manajemen Pusat Kegiatan Belajar Masyarakat dalam Meningkatkan Mutu Layanan Pendidikan Nonformal. Jurnal IImiah VISI PPTK PAUDNI $11(2), 232$.

Septiani. 2016. Pengalaman Pusat Kegiatan Belajar Masyarakat (PKBM) dalam Memfasilitasi Masyarakat Belajar Sepanjang Hayat. Jurnal IImiah VISI PPTK PAUDNI, 10 (2), 67-76 journal.unj.ac.id/jurnalfip/index.php/visi/article/download/13/16, diakses tanggal 29 Maret 2017

Setyawati. 2015. Aspirasi Orangtua Terhadap Pendidikan Anak (Studi Kasus di Keluarga Nelayan Pantaisari Kelurahan Panjang Wetan Kecamatan Pekalongan Utara Kota Pekalongan). Skripsi, Universitas Negeri Semarang. http://lib.unnes.ac.id/23014/1/1201411039.pdf diakses tanggal 24 Juli 2017

Silalahi. 2009. Metode Penelitian Sosial. Bandung: PT. Refika Aditama

Sutisna, Sinaga, \& Rosfiantika. 2012. Peranan PKBM (Pusat Kegiatan Belajar Masyarakat) dalam Menumbuhkan Minat Baca Warga Belajar, eJurnal Mahasiswa Universitas Padjadjaran 1(1), http://jurnal.unpad.ac.id/journal/article/view/ 1287/pdf diakses tanggal 29 Maret 2017

Tohani. 2009. Evaluasi Pelaksanaan Program Pusat Kegiatan Belajar Masyarakat (PKBM) dalam konteks Pemberdayaan Masyarakat di Daerah Istimewa Yogyakarta. Jurnal Penelitian IImu Pendidikan, 2(2) (194-205). http://journal.uny.ac.id/index.php/jpip/article /viewFile/4618/ 3965, diakses tanggal 29 Maret 2017

Wasak. 2012. Keadaan Sosial-Ekonomi Masyarakat Nelayan di Desa Kinabuhutan Kecamatan Likupang Barat Kabupaten Minahasa Utara, Sulawesi Utara. Pacific Journal, 1(7),13391342, http://repo.unsrat.ac.id/280/1/Keadaan_Sosial-Ekonomi_Masyarakat Nelayan_di_Desa_Kinabuhutan_Kecamatan _Likupang_Barat._Kabupaten_Minahasa Utara\%2c_Sulawesi_Utara.pdf, diakses tanggal 24 April 2017 